\title{
Proceeding
}

8th INSHS International Christmas Sport Scientific Conference, 5-7 December 2013. International Network of Sport and Health

Science. Szombathely, Hungary

\section{Effect of a modified pilates programme on flexion of spine at women with a sedentary job}

\author{
DAGMAR HRUSOVA , BLAHOSLAV KOMESTIK \\ Department of Leisure and Tourism, Faculty of Informatics and Management, University of Hradec Kralove, Czech \\ Republic.
}

\begin{abstract}
Hrusova, D. \& Komestik, B. (2014). Effect of a modified pilates programme on flexion of spine at women with a sedentary job. J. Hum. Sport Exerc., 9(Proc1), pp.S284-S290. The supposed effect of pilates is based on its characteristics and key principles (core, concentration, control, precision, breath, and flow) referring to effective activation and optimal function of deep stabilizing system (core) as a precondition of correct muscle involvement and effective movement. It is also important to modify the exercise so that it is for individual convenience. Pilates is often recommended in clinical practice as a therapy for functional muscle disorders. The research study is focused on flexibility of spine. Flexion represents the biggestamplitude motion of spine and it can frequently be limited as a consequence of changes in function. The aim was to determine the effect of a three-month regular and targeted modified pilates exercise programme on flexibility of spine in flexion. The problem was solved by empirical, causal research - quasi experiment, with both quantitative and qualitative data analysis. The sample comprised 21 subjects - women at working age, with a sedentary job. To diagnose the dependant variable three selected indicators were used - direct somatometric diagnostic tests of function of spine, which are commonly used in a clinical practice: Thomayer test, Schober and Stibor distances. The intervention programme went on in the range of three months, with a frequency of three sixty-minute lessons a week; the subjects underwent pre-test and posttest measurements. The data were analysed by non-parametric statistical tests for dependant choices (sign test and Wilcoxon pair test; $p<0.05$ ) and criteria based on a consensus of expert opinions to determine the significance of difference. Based on the set conditions of verification, the total results did not show a significant difference between pre-test and post-test. Key words: PILATES INTERVENTION; EXERCISE THERAPY; FLEXIBILITY; OPTIMAL FUNCTION; TESTS OF SPINE.
\end{abstract}

Corresponding author. Department of Leisure and Tourism, Faculty of Informatics and Management, University of Hradec Kralove, Czech Republic.

E-mail: dagmar.hrusova@uhk.cz

8th INSHS International Christmas Sport Scientific Conference, 5-7 December 2013. International Network of Sport and Health Science. Szombathely, Hungary.

JOURNAL OF HUMAN SPORT \& EXERCISE ISSN 1988-5202

(c) Faculty of Education. University of Alicante

doi: 10.14198/jhse.2014.9.Proc1.11

VOLUME 9 | Proc1 | 2014 | S284 


\section{INTRODUCTION}

Pilates exercise system has existed for about a hundred years. It can improve physical condition and also serves as preventive and compensatory exercise. The effect of the exercise is based on its characteristics and applied principles (core, concentration, control, precision, breath, and flow) relating to proper activation and optimal function of the deep stabilization system, as a precondition of effective movement and proper muscle function. However, an exercise programme must be adapted to individual needs of participants, adjusted to physical limitations and thus prevent potential problems. Modifications respect the key pilates principles and are considered an important part of the traditional pilates method (Gagnon, 2005; Rydeard, Leger \& Smith, 2006; Klenková \& Kazimír, 2010; Kloubec, 2010; Blahušová, 2010).

The aim of this study was to determine the effect of the designed intervention on flexibility of spine in flexion, and to verify positive effect of a modified pilates programme, in accordance with general findings on effects of a convenient exercise therapy on musculoskeletal system (Hauggaard \& Persson, 2007). This work should help in theory and practice and optimized programme could be applied in the field of therapy and prevention of changes in function of musculoskeletal system. The research is based on the fact that the main employed position in pilates is a neutral position of spine and pelvis, which facilitates optimal flexibility of spine, according to Panjabi (1992). Blahušová (2010) analyzed pilates from the point of view of basic movements and found that most exercises are oriented in flexion (60\%). Pilates is a comprehensive strengthening and stretching system with a balance and harmonious muscle cooperation, with an emphasis on breathing technique. Proper breathing is important because respiratory movements interact with flexibility of spine, as approved by Véle (2003), Kolář (2007), and Suchomel (2006). Proper breathing helps facilitate muscle contraction of deep stabilizing system of spine (Hodges et al., 2003).

The basis for the problem was that a positive effect of pilates-based exercise therapy is generally recognized. At the time of projecting the research, however, there was not sufficient evidence, which was also approved by Kloubec (2010), and Taylor et al. (2011). Effect of pilates on the musculoskeletal system in healthy subjects was analyzed in a systematic review of Cruz- Ferreira et al. (2011). La Touche et al. (2008), Lim et al. (2011), and Pereira et al. (2012) accomplished systematic reviews of the effect of pilates on chronic nonspecific low back pain. Segal et al. (2004), and Sekenditz et al. (2007) investigated effect of pilates on flexibility of spine and other selected variables. Their findings showed that pilates can affect flexibility in the lumbar spine. In the lumbar section of spine O'Brien et al. (2006), Curnow et al. (2009) and Rydeard et al. (2006) also focused on the lumbar - pelvic stabilization and based on the results suggested a statistically significant improvement in stabilizing function.

In diagnosis and therapy of changes in function, Koláŕ (1997) suggested three system levels: central nervous system, muscles and joints. In the joint level there exist two basic types of functional disorders hypermobility and limited (reduced) joint mobility. The spine mobility anatomically depends on several factors - it is determined by the sum of partial mobility of each section, it depends on the intervertebral joints, intervertebral disks and mobility and stiffness of muscles and ligaments connecting individual segments. An optimal range of motion depends e.g. on the age of the individual, level of motor abilities, height of the intervertebral discs, ligaments and intervertebral muscles. Yet there exist norms for the standardized tests of spine flexibility (Kolář, 2009; Haladová \& Nechvátalová, 1997; Králová \& Matějičková, 1985). A large range of motion is allowed in the lumbar spine section. Its function is related to pelvic area and hip joint. According to Kolár (2009), also abdominal and lateral muscles can be ranged with lumbar spine muscles as to the function. The lumbar spine is the most mechanically-loaded section of the spine, which can lead to an increased risk of changes in function and disorders (Lewit, 1990). This can very often 
limit a range of spine flexion. Vařeka \& Vařeková (1995) itemized possible causes of the flexion limitations: shortened ischiocrural muscles, shortened back muscles, shortened musculus quadratus lumborum, sacral-iliac blockade, and blockade of lumbar spine or radicular syndrome.

\section{MATERIAL AND METHODS}

The aim of the research was to determine the effect of a three-month regular and targeted modified pilates exercise programme on the flexibility of spine in flexion. Based on a literature review, the essential aspects were analyzed regarding the function of musculoskeletal system, the diagnostic methods detecting changes in the flexibility of spine in flexion, and the design and optimization of an exercise program with focus on the key pilates principles. It was assumed that regular and targeted modified pilates exercise programme will improve flexibility of spine in flexion. There were three selected indicators of spine flexion: Thomayer test (non-specific overall flexibility of spine in flexion), Schober distance (flexibility of lumbar spine in flexion), and Stibor distance (flexibility of lumbar + thoracic spine in flexion). The problem was solved by an empirical, causal research - quasi experiment, with both quantitative and qualitative data analysis. The intervention was based on a modified pilates exercise programme (individualized approach), with an exercise frequency of sixty minutes three times a week for three months. In total there were 33 exercise classes. Participants were diagnosed in pre-test and post-test measurements.

\section{Participants}

Research sample comprised 23 participants, selected by a deliberate statistical choice, 21 of whom met the criterion of attendance ( $85 \%$ of classes). All the participants were women at working age (22 - 64 years), pregnancy excluded. The arithmetic average age was approximately 44 , and the distribution of age groups was: $22-29$ years: $19 \%, 30-39$ years: $19 \%, 40-49$ years: $19 \%, 50-59$ years: $24 \%, 60-64$ years: $19 \%$ ). In terms of the age the sample was heterogeneous, however, in terms of the prevailing character of work (routine or creative intellectual activity, sedentary work - daily average of sitting: $81 / 4$ hours, non-specific low back pain and almost no previous experience with pilates), the sample can be considered homogeneous. The main criteria for inclusion in the research sample was character of work (sedentary), no previous experience with pilates, being without an injury and rehabilitation in the past six months, and voluntary participation (a written agreement).

\section{Measures}

The qualitative methods of content analysis and synthesis were used to review relevant sources. Questionning was used as a method for deliberate selection of the participants - a technique of structured questionnaire with reference to the inclusion criteria. Participants were measured to obtain the basic somatometric data (body weight, body height, and body mass index). The flexibility of spine in flexion was diagnosed by direct somatometric tests, a method of measurement. The selected tests of function examine an active range of motion, based on the changing distance of procesus spinosus in flexion. The tests evaluate function of spine as a whole or in the selected sections of the spine, as shown in figure 1. The tests are standardized descriptive methods, convenient for statistical analysis, and recommended and applied in clinical practice, as a supplementary examination to posture (Haladová \& Nechvátalová, 1997; Lewit, 1990; Suchomel \& Lisický, 2004; Véle, 1995).

Thomayer test evaluates a non-specific flexibility of spine in flexion. It measures an absolute distance from daktylion to the floor at forward bend (see figure 1). An ideal value for qualitative analysis, based on optimal function, is the difference of 0 centimeters. Schober distance evaluates flexibility of spine in flexion in the lumbar section. It measures an absolute difference of the distances of the intersection of the spine and 
spinae iliacae posteriori superiores to the point measured $10 \mathrm{~cm}$ cranially from the marked intersection, when standing and at forward bend (see figure 1). The distance should extend at least $5 \mathrm{~cm}$, according to Koláŕ (2009), and Vařeka \& Vařeková (1995). Králová \& Matějičcková (1985) suggested an optimal extension of $4-6 \mathrm{~cm}$. An ideal value for qualitative analysis, based on optimal function, is the median of the range of optimal function. Stibor distance evaluates flexibility of spine in flexion in the lumbar + thoracic section. It measures an absolute difference of the distances of the intersection of the spine and spinae iliacae posteriori superiores (as above in Schober distance) to the $\mathrm{C} 7$ procesus spinosus, when standing and at forward bend (see figure 1). The distance should extend at least by $7-10 \mathrm{~cm}$, according to Kolár (2009), Vařeka \& Vařeková (1995), and Králová \& Matějíčková (1985). An ideal value for qualitative analysis, based on optimal function, is the median of the range of optimal function.

\section{Analysis}

The research is based on quantitative and qualitative analysis. Data were organized and processed by means of mathematical and statistical methods using computer software Statistica 10 and Microsoft Excel. The statistical significance of the difference was evaluated by nonparametric tests for dependent samples (sign test and Wilcoxon paired test), at the level of statistical significance of $p<0.05$. In qualitative analysis the logical significance was evaluated according to the criteria based on the consensus of expert opinions $(n=3)$. These criteria were established by determination of the minimum intervention effect, using the relative frequency of improvements (at least $50 \%$ of cases) and zero absolute frequency of impairments between pre-test and post-test. The parallel validity of both criteria was required. With regard to the expert opinions, the minimal required change was $1 \mathrm{~cm}$ in Thomayer test and $0.5 \mathrm{~cm}$ in Schober and Stibor distance. To support the research hypothesis, a significant difference was calculated based on both quantitative and qualitative analyses.

\section{RESULTS}

The three selected indicators (Thomayer test, Schober distance, and Stibor distance) were used to verify the research hypothesis about the effect of a regular and targeted modified pilates exercise programme on spine flexibility in flexion. Thomayer test evaluates non-specific flexibility of the whole spine in flexion. The data distribution was changed and the absolute measured distance of daktylion from the floor decreased in terms of optimization of the function. The median value between pre-test and post-test decreased from 6.5 $\mathrm{cm}$ to $3 \mathrm{~cm}$ and the modus value in post-test was 0 in six cases, detecting an optimal function. The average value of the distance difference was decreased by $3.4 \mathrm{~cm}$. Both statistical tests (sign and Wilcoxon pair test) showed a significant difference $(p<0.05)$ as shown in table 1 and table 2 . Also the criteria set by expert opinions supported the significance of the differences in Thomayer test (see table 3). Improvement occurred in $78 \%$ of cases. The first hypothesis was confirmed.

Schober distance evaluates the flexibility of spine in flexion in the lumbar section. There was a certain shift of the measured values of the second and third quartile from the interval $4-5 \mathrm{~cm}$ to the interval $5-6 \mathrm{~cm}$, the average value of the difference was increased by $0.16 \mathrm{~cm}$. The median remained the same, $5 \mathrm{~cm}$. However, neither statistical tests (sign and Wilcoxon pair test, see table 1 and table 2) proved significant difference $(p<0.05)$, nor qualitative analysis based on the criteria of expert opinions proved significant difference (see table 3). Although some improvement occurred in $69 \%$ of cases, in 2 cases there was impairment. The parallel validity of both criteria was requested. The second hypothesis was not confirmed.

Stibor distance evaluates the flexibility of spine in flexion in the lumbar and thoracic section. There was a certain shift of the measured values of the second and third quartile from $8-11$ in pretest to 9 - 11 in post- 
test. The median value increased from $9.5 \mathrm{~cm}$ to $10 \mathrm{~cm}$, and the average value of the distance difference was increased by $0.22 \mathrm{~cm}$. However, neither statistical tests (sign test - see table 1, and Wilcoxon pair test - see table 2) proved significant difference $(p<0.05)$, nor qualitative analysis based on the criteria of expert opinions proved significant difference (see table). The minimum requested relative frequency of improvements did not exceed the criterion, as the improvement occurred only in $48 \%$ of cases. At the same time there was impairment in 3 cases. The difference between pre-test and post-test does not appear to be significant, the third hypothesis was not confirmed.

The research hypothesis, that regular and targeted modified pilates exercise programme would improve flexibility of the spine in flexion, was not confirmed. The total results do not show a significant difference, with regard to the set conditions of verification.

\section{DISCUSSION}

The aim of the diagnostic was to determine the changes of the selected distances in spine flexion. The main diagnostic tools were tests of spine function, which are standardized methods that offer values of "norm" - optimal function (Kolář, 2009; Haladová \& Nechvátalová, 1997; Králová \& Matějíčková, 1985). The tests are recommended in clinical practice (Lewit 1990; Véle, 1995; Suchomel \& Lisický, 2004) and considered to be an important part in the strategy of therapy and prevention of vertebrogenic disorders. The used tests of the spine function are objective and standardized methods convenient for statistical analysis in academic research (Vařeka \& Vařeková, 1995). However, there are some factors that can affect the results - such as age, somatometric and anatomic characteristics and other factors described below. This can be partly prevented by homogeneity of the sample.

In Thomayer test, a nonspecific indicator of flexibility of spine in flexion, a significant difference was calculated in both quantitative and qualitative analyses. In the indicators of flexibility of lumbar and lumbar + thoracic section of spine in flexion neither quantitative nor qualitative analysis showed a significant difference. There were certain minor improvements between pre-test and post-test (in 9 cases in Schober distance, and in 10 cases in Stibor distance), but at the same time several participants worsened in the given indicators (in 2 cases in Schober distance, and in 3 cases in Stibor distance). The different results of individual hypotheses may have been caused due to the specifics of individual tests. Results of the Thomayer test may be influenced by the ratio of the length of the limbs and trunk (Vařeka \& Vařeková, 1995), and shortened knee flexors. It is also very important to control the fluency of forward bend and the knees extended. Improved results between pre-test and post-test therefore do not have to give evidence only of the increased flexibility of the spine, but simultaneously may be due to improvements in function of the knee flexors. Despite this fact, the test is commonly used as an indicator of flexibility of spine in flexion, which was also suggested by other authors (Kloubec, 2010; Sekenditz et al., 2007; Segal et al., 2004). The mentioned authors' conclusions appear to suggest that pilates may have impact on improving the flexibility of spine in flexion, however, this may be partly due to improved function of knee flexors. It can be suggested for this effect to be reduced and controlled, to examine the function of knee flexors (e.g. Janda, 1974) prior to the tests of flexibility of spine. The study was focused on non-specific flexibility of spine in flexion and the lumbar and lumbar + thoracic spine in flexion. For further research on the effect of exercise therapy on spinal flexibility, to obtain more comprehensive results on flexibility of spine in its individual sections, it can be recommended to diagnose an active range of motion also in the thoracic (Otto distance) and cervical spine (Čepojev distance). 


\section{CONCLUSIONS}

The aim of this study was to determine the effect of three-month regular and targeted modified pilates exercise programme on flexibility of spine in flexion. The aim was accomplished; the modified exercise programme based on the principles of pilates was empirically verified. The results appear to suggest an improvement in non-specific flexibility of spine in flexion. However, the difference does not appear to be significant in the case of lumbar and lumbar + thoracic spine. This may be due to an influence of knee flexors. In conclusion, with regard to the defined conditions of verification, the total results did not suggest a significant difference between pre- test and post-test. An expected use of the pilates exercise programme in practice is both for prevention and therapy of changes in function of musculoskeletal system. Pilates may influence musculoskeletal system in more aspects and therefore should be a course of further study.

\section{REFERENCES}

1. Blahušová, E. (2010). Pilates pro rehabilitaci: zdravé cvičení bez bolesti. Praha: Grada Publishing.

2. Cruz-Ferreira, A. et al. (2011). A systematic review of the effects of pilates method of exercise in healthy people. Arch Phys Med Rehabil, 92(12), pp.2071-2081.

3. Čumpelík, J. et al. (2006). Vztah mezi dechovými pohyby a držením těla. Rehabilitace a fyzikální lékařství, 2, pp.62-70.

4. Curnow, D. et al. (2009). Altered motor control, posture and the Pilates method of exercise prescription. Journal of Bodywork \& Movement Therapies, 13(1), pp.104-111.

5. Gagnon, L.H. (2005). Efficacy of Pilates exercises as therapeutic entervention in treating patiens with low back pain. Knoxville: The University of Tenessee. [Dissertation thesis].

6. Haladová, E. \& Nechvátalová, L. (1997). Vyšetřovací metody hybného systému. 1. vyd. Brno: Institut pro další vzdělávání pracovníků ve zdravotnictví. 137s.

7. Hauggaard, A. \& Persson, A.L. (2007). Specific spinal stabilisation exercises in patients with low back pain - a systematic review. Physical Therapy Review, 12, pp.233-248.

8. Hodges, P.W. (2003). Core stability exercise in chronic low back pain. Orthopaedic Clinical North America, 34(2), pp.245-254.

9. Janda, V. (1974). Vyšetřování hybnosti [I]. Praha: Avicenum.

10. Klenková, M. \& Kazimír J. (2010). Bolesti v křiži a pilates medical. Praha: Slovart.

11. Kloubec, J.A. (2010). Pilates for improvement of muscle endurance, flexibility, balance, and posture. J Strenght Cond Res, 24(3), pp.661-667.

12. Kolář, P. (2009). Kineziologie páteře, pánve a hrudníku. pp.128-143. In Kolář, P. et al. Rehabilitace v klinické praxi. Praha: Galén.

13. Kolář, P. (2007). Vertebrogenní obtíže a stabilizační funkce páteře - terapie. Rehabilitace a fyzikální lékařství, 1, pp.3-17.

14. Kolář, P. (1997). Funkční poruchy pohybového systému. pp. 227-234. In Dylevský, I. et al. Pohybový systém a zátěž. Praha: Grada Publishing.

15. Králová, M. \& Matějíčková, V. (1985). Rehabilitace u revmatických nemocí. Praha, Avicenum.

16. La Touche, R., Escalante, K. \& Linares, M.T. (2008). Treating non-specific chronic low back pain through the Pilates method. Journal of Bodywork \& Movement Therapies, 12(4), pp.364-370.

17. Lewit, K. (1990). Manipulační léčba v rámci léčebné rehabilitace. Praha: Nakladatelství dopravy a spojů.

18. Lim, E.C. (2011). et al. Effects of pilates-based exercises on pain and disability in individuals with persistent nonspecific low back pain: A systematic review with meta-analysis. J Orthop Sporth Phys, 41(2), pp.70-80. 
19. O'Brien, N., Hanlon, M. \& Meldrum, D. (2006). Randomized Controlled Trial Comparing Physiotherapy and Pilates in the Treatment of Ordinary Low Back Pain. Physical Therapy Reviews, 11(3), pp.224-225.

20. Panjabi, M.M. (1992). The stabilizing system of the spine. Part I. Function, dysfunction, adaptation, and enhancement. J Spinal Disord, 5(4), pp.383-389.

21. Pereira, L.M. et al. (2012). Comparing the pilates method with no exercise or lumbar stabilization for pain and functionality in patients with chronic low back pain: systematic review and metaanalysis. Clin Rehabil, 26(1), pp.10-20.

22. Rydeard, R., Leger, A. \& Smith, D. (2006). Pilates-based therapeutic exercise: effect on subjects with nonspecific chronic low back pain and functional disability: a randomized controlled trial. $J$ Orthop Sport Phys, 36(7), pp.472-484.

23. Segal, N.A., Hein, J. \& Basford, J.R. (2004). The effects of pilates training on flexibility and body composition: an observational study. Arch Phys Med Rehab, 85(12), pp.1977-1981.

24. Sekenditz, B. et al. (2007). Effects of Pilates exercise on trunk strength, endurance and flexibility in sedentary adult females. Journal of Bodywork \& Movement Therapies, 11(4), pp.318-326.

25. Suchomel, T. (2006). Stabilita v pohybovém systému a hluboký stabilizační systém - podstata a klinická východiska. Rehabilitace a fyzikální lékařství, 3, pp.112-124.

26. Suchomel, T. \& Lisický, D. (2004). Progresivní dynamická stabilizace bederní páteře. Rehabilitace a fyzikální lékařství, 43, pp.128-136.

27. Taylor, L., Hay-Smith, E.J.C. \& Dean, S. (2011). Can clinical pilates decrease pain and improve fiction in people complaining of non-specific low back pain? A pilot study. New Zealand Journal of Physiotherapy, 39(1), pp.30-38.

28. Vařeka, I. \& Vařeková, R. (1995). Přehled klinických metod vyšetření stoje a funkčních testů páteře. Olomouc: Univerzita Palackého.

29. Véle, F. (1995). Kineziologie posturálního systému. Praha: Karolinum.

30. Véle, F. (2003). Kineziologický pohled na vztah dechových pohybů k prevenci posturálních poruch a vadného držení. Rehabilitace a fyzikální lékařství, 1, pp.46. 